\title{
Do Hedge Funds Hedge in Recent 20 Years?
}

\author{
Boya $\mathrm{Di}^{1}$, Shuming Zhao ${ }^{2}$, Yuting Lei ${ }^{3}$, ZhiHao Ke ${ }^{4}$, Gaohao Zhu ${ }^{5}$, Ziyuan Kang ${ }^{6}$ \\ ${ }^{1}$ College of Agriculture \& Environmental Sciences, University of California, Davis, 95616, USA, \\ boyadi99_ucdavis@outlook.com \\ ${ }^{2}$ Sierra Canyon School, Chatsworth, CA 91311, USA, Shuming.Zhao@scsstudent.org \\ ${ }^{3} X i$ 'an International Studies University, Xi'an, Shaanxi 710128, China, 1412567586@qq.com \\ ${ }^{4}$ School of Global Finance, Fordham University, New York, 10001, USA, 2583977172@qq.com \\ ${ }^{5}$ BASIS Independent Silicon Valley, San Jose 95126, USA, robinzgh@gmail.com \\ ${ }^{6}$ Henan Experimental High School, Zhengzhou, Henan 450011, China, 2077508975@qq.com
}

\begin{abstract}
This work does a follow-up study on Do Hedge Funds Hedge? focuses on the returns of hedge fund industry, and finds how its reported returns are resistant to market fluctuations. In this work, monthly data for different hedge funds and S\&P 500 are compared, to generate correlation between them over various periods. As a result, a huge discrepancy between the changing volatility and hedge fund stable returns recommends the investors to review the reports given by hedge fund companies, which are possibly manipulated with strategies to highlight high returns and low risks over time. This work indicates a continuous trend in the hedge fund industry that is proven by the previous study, in the more recent timeframe, providing investors with insights to the reported returns over market risks.
\end{abstract}

Keywords: Hedge Funds, S\&P 500, Sharpe Ratio, Excess Return, Portfolio Management

\section{INTRODUCTION}

Although faced with the severe challenge of the COVID-19, the hedge fund industry still had a remarkable return, with an annual profit of $8.68 \%$ in 2020 [1]. In fact, the hedge fund industry had positive returns in four of the past five years, and hardly experienced negative monthly returns that were worser than $-2 \%$ in magnitude [1]. Investors usually assume that hedge funds added diversification to their portfolios and provided them with lower risks and higher returns. The hedge fund is an investment method that consists of various strategies such as derivatives and leverage, and serves as an active alpha for investors to get high returns from pooled funds [2]. Many hedge funds take advantage of the illiquid exchange-traded securities, as well as the difficult-toprice over-the-counter securities, as they don't require an instant reaction to price changes. In addition, such securities are usually traded at the end of the month or approaching to the end of the month, which presents hedge funds some accessibility to manage their monthly reports.

In fact, hedge fund managers are very sensitive to market frictions, and they have much more motivations to show their extraordinary manager skills to attract investors when they are faced with a low investor demand
[3]. This partially explains why hedge fund managers might cover up losses or low returns in reports, as they try to convince the investors with skills and ensured confidence to their portfolios. However, people are often curious about whether hedge funds hedge.

Asness, Krail and Liew discussed this question in the paper "Do Hedge Funds Hedge?"[4] by analyzing monthly returns of the CSFB/Tremont index of hedge funds from 1994 to 2000 (2000 Dataset). They suggested that the favorable reports by hedge fund managers might mislead people as the statistics about returns were likely to be overestimated, and there were indications of delay in reporting and underestimation of market risks [4]. The author agrees with this research results about the overestimation. However, the dataset used in the previous paper seems outdated. Therefore, the author proposes a follow-on study of the "Do Hedge Fund Hedge?" to generalize a new set of data from 1994 to the March of 2021 [5] and applies the same research method to see if the inaccuracy of the reported returns occurs alike in recent years, and how the trend changes in the new period.

The research argued that the inaccuracy of monthly returns was an intentional behavior when the team analyzed the risks by using the monthly beta and the 
correlation to compare with the actual exposure rates and find out the discrepancy. Besides the significant diversification that hedge funds exerted on traditional portfolios, the non-synchronous patterns were found between monthly S\&P 500 returns and these monthly reported hedge fund returns. In addition, among most of the hedge fund subcategories, there were no significant values added as they had been expected, which revealed the inaccuracy in the reports of hedge funds. By computing the data monthly, and especially doing a contrast in every 6 months, there was a clear discrepancy between reported values and the actual market prices. Namely, the reports of hedge funds underestimated the actual market exposures of the hedge funds.

Moreover, the problem that hedge funds may intentionally contain delayed information of returns still exists in the 2021 dataset. The team found that hedge funds often used either last traded prices or estimated prices of the current market to show the trend to the investors that values were continuously added to their portfolios. In fact, the returns studied in this paper are much more associated with the changes in market risks, instead of managers' skills or characteristics. The author found that the hedge fund managers might make use of some returns in later months to cover the partial losses in previous months, which made the reported returns pleasing and show a continuous growth.

This paper will make a compare and contrast to the previous research results from the selected point of views. First, this paper will analyze the monthly returns from different period in terms of annualized excess returns, standard derivations, and the statistics of Sharpe ratios. Then, this paper will generate monthly regression data for the 2021 dataset. Finally, this paper will compare and contrast the volatility and market correlation between the 2000 dataset and 2021 dataset. However, this paper will not discuss issues like hedge fund alphas, lagged betas and asymmetric betas that has been analyzed in previous research.

\section{DATA}

All data used in the paper "Do Hedge Fund Hedge?" and this paper are from CSFB/Tremont hedge fund indexes, primarily the monthly returns. The difference is that Asness, Krail and Liew analyzed the data from January 1994 to September 2000 while the author in this paper extends the time period from January 1994 to February 2021 in order to reflect the most recent trends.

Containing ten subcategories, CSFB/Tremont hedge fund indexes include only funds to formulate an assetweighted hedge fund index on a monthly basis [2]. Applying a rules-based methodology, CSFB/Tremont hedge fund indexes identify the index universe with three basic criteria to achieve maximization representation: "a minimum of $\$ 50$ million assets under management ("AUM"); a minimum one-year track record; and current audited financial statements" [6]. Currently, CSFB/Tremont hedge fund indexes track about 9,000 funds' net performance [6].

The CSFB/Tremont hedge fund indexes also make use of fund weight caps to diverse the portfolio and reduce concentration risk [6]. Besides, the CSFB/Tremont hedge fund indexes only remove funds if they are fully liquidated or fail to meet the audited financial statements requirement to minimize survivorship bias [6]. This might be the reason why the sub-category of Dedicated Short Bias hedge fund index was removed since February 2017. The author believes this different constituent of the indexes may affect the final results of this paper when compare the Aggregate Hedge Fund Index and the Dedicated Short Bias Hedge Fund Index under different time frames. Therefore, this paper only uses data before February 2017 to analyze this specific subcategory.

Table 1. HEDGE FUND RETURNS—MONTHLY DATA JANUARY 1994-SEPTEMBER 2000

\begin{tabular}{|c|c|c|c|c|c|c|c|c|}
\hline \multirow{3}{*}{ Portfolio } & $\begin{array}{l}\text { Annualiz } \\
\text { ed }\end{array}$ & $\begin{array}{l}\text { Annualiz } \\
\text { ed }\end{array}$ & $\begin{array}{l}\text { Annualiz } \\
\text { ed }\end{array}$ & $\begin{array}{l}\text { Correlati } \\
\text { on }\end{array}$ & $\underset{\mathrm{m}}{\operatorname{Maximu}}$ & Month of & $\underset{\mathrm{m}}{\text { Minimu }}$ & $\begin{array}{c}\text { Month } \\
\text { of }\end{array}$ \\
\hline & Excess & Standard & Sharpe & With S\&P & Monthly & $\underset{\mathrm{m}}{\operatorname{Maximu}}$ & Monthly & $\underset{\mathrm{m}}{\operatorname{Minimu}}$ \\
\hline & Return & Deviation & Ratio & 500 & Return & Return & Return & Return \\
\hline $\begin{array}{l}\text { Aggregate Hedge } \\
\text { Fund Index }\end{array}$ & $8.00 \%$ & $10.00 \%$ & 0.80 & 0.52 & $8.10 \%$ & $12 / 99$ & $-0.80 \%$ & $08 / 98$ \\
\hline $\begin{array}{l}\text { Convertible } \\
\text { Arbitrage }\end{array}$ & $5.40 \%$ & $5.10 \%$ & 1.07 & 0.13 & $3.10 \%$ & $04 / 00$ & $-5.10 \%$ & $08 / 98$ \\
\hline Event-Driven & $7.00 \%$ & $6.70 \%$ & 1.05 & 0.60 & $3.40 \%$ & $01 / 94$ & $-12.20 \%$ & $08 / 98$ \\
\hline $\begin{array}{l}\text { Equity Market- } \\
\text { Neutral }\end{array}$ & $6.40 \%$ & $3.50 \%$ & 1.85 & 0.48 & $2.80 \%$ & $07 / 97$ & $-1.60 \%$ & $03 / 97$ \\
\hline
\end{tabular}




\begin{tabular}{|c|c|c|c|c|c|c|c|c|}
\hline $\begin{array}{l}\text { Fixed-Income } \\
\text { Arbitrage }\end{array}$ & $1.60 \%$ & $4.40 \%$ & 0.36 & 0.08 & $1.50 \%$ & 04/95 & $-7.30 \%$ & $10 / 98$ \\
\hline Long/Short Equity & $11.80 \%$ & $12.60 \%$ & 0.94 & 0.62 & $12.60 \%$ & $12 / 99$ & $-11.90 \%$ & 08/98 \\
\hline $\begin{array}{l}\text { Emerging } \\
\text { Markets }\end{array}$ & $2.30 \%$ & $20.80 \%$ & 0.11 & 0.50 & $16.10 \%$ & $08 / 94$ & $-23.40 \%$ & $08 / 98$ \\
\hline Global Macro & $7.70 \%$ & $14.40 \%$ & 0.54 & 0.36 & $10.10 \%$ & $08 / 95$ & $-11.90 \%$ & $10 / 98$ \\
\hline Managed Futures & $-1.20 \%$ & $11.10 \%$ & -0.10 & 0.01 & $9.50 \%$ & $08 / 98$ & $-9.80 \%$ & 08/95 \\
\hline $\begin{array}{l}\text { Dedicated Short } \\
\text { Bias }\end{array}$ & $-7.10 \%$ & $18.60 \%$ & -0.38 & -0.76 & $22.30 \%$ & $08 / 98$ & $-9.10 \%$ & $02 / 00$ \\
\hline S\&P 500 & $14.60 \%$ & $14.20 \%$ & 1.03 & 1.00 & $9.30 \%$ & $03 / 00$ & $-14.90 \%$ & 08/98 \\
\hline
\end{tabular}

Table 2. HEDGE FUND RETURNS-MONTHLY DATA JANUARY 1994-FEBRUARY 2021

\begin{tabular}{|c|c|c|c|c|c|c|c|c|}
\hline \multirow{3}{*}{ Portfolio } & $\begin{array}{l}\text { Annualiz } \\
\text { ed }\end{array}$ & $\begin{array}{l}\text { Annualiz } \\
\text { ed }\end{array}$ & $\begin{array}{l}\text { Annualiz } \\
\text { ed }\end{array}$ & $\begin{array}{l}\text { Correlati } \\
\text { on }\end{array}$ & $\begin{array}{c}\text { Maximu } \\
\mathrm{m}\end{array}$ & $\begin{array}{c}\text { Month } \\
\text { of }\end{array}$ & $\begin{array}{c}\text { Minimu } \\
\mathrm{m}\end{array}$ & $\begin{array}{c}\text { Month } \\
\text { of }\end{array}$ \\
\hline & Excess & $\begin{array}{l}\text { Standar } \\
\quad d\end{array}$ & Sharpe & $\begin{array}{l}\text { With } \\
\text { S\&P }\end{array}$ & Monthly & $\underset{\mathrm{m}}{\operatorname{Maximu}}$ & $\begin{array}{c}\text { Monthl } \\
y\end{array}$ & $\underset{\mathrm{m}}{\operatorname{Minimu}}$ \\
\hline & Return & $\begin{array}{c}\text { Deviatio } \\
\mathrm{n}\end{array}$ & Ratio & 500 & Return & Return & Return & Return \\
\hline $\begin{array}{l}\text { Aggregate Hedge } \\
\text { Fund Index }\end{array}$ & $4.54 \%$ & $6.73 \%$ & 0.67 & 0.40 & $8.50 \%$ & $12 / 99$ & $-7.60 \%$ & $08 / 98$ \\
\hline Convertible Arbitrage & $3.77 \%$ & $6.18 \%$ & 0.61 & 0.34 & $5.80 \%$ & 05/09 & $12.60 \%$ & $08 / 10$ \\
\hline Event-Driven & $4.90 \%$ & $6.63 \%$ & 0.74 & 0.54 & $6.80 \%$ & $11 / 20$ & $13.50 \%$ & $03 / 20$ \\
\hline Equity Market-Neutral & $1.12 \%$ & $8.82 \%$ & 0.13 & 0.23 & $4.30 \%$ & $07 / 20$ & $40.50 \%$ & $11 / 08$ \\
\hline $\begin{array}{l}\text { Fixed-Income } \\
\text { Arbitrage }\end{array}$ & $2.31 \%$ & $5.11 \%$ & 0.45 & 0.31 & $4.30 \%$ & 05/09 & $14.00 \%$ & $10 / 08$ \\
\hline Long/Short Equity & $5.46 \%$ & $8.91 \%$ & 0.61 & 0.42 & $13.00 \%$ & $12 / 99$ & $11.40 \%$ & 08/98 \\
\hline Emerging Markets & $4.26 \%$ & $13.01 \%$ & 0.33 & 0.39 & $16.40 \%$ & $08 / 94$ & $23.00 \%$ & $08 / 98$ \\
\hline Global Macro & $6.42 \%$ & $8.46 \%$ & 0.76 & 0.13 & $10.60 \%$ & $08 / 95$ & $11.60 \%$ & $10 / 98$ \\
\hline Managed Futures & $1.68 \%$ & $11.14 \%$ & 0.15 & -0.11 & $10.00 \%$ & $08 / 98$ & $-9.40 \%$ & 09/95 \\
\hline Dedicated Short Bias & $-8.44 \%$ & $16.12 \%$ & -0.52 & -0.53 & $22.70 \%$ & $08 / 98$ & $11.30 \%^{-}$ & $09 / 10$ \\
\hline S\&P 500 & $7.33 \%$ & $13.87 \%$ & 0.53 & 1.00 & $20.16 \%$ & 08/09 & $30.41 \%$ & 06/08 \\
\hline
\end{tabular}

\subsection{Hedge Fund Summary Statistics}

Table I and Table II provide not only the monthly hedge fund returns from January 1994 to September 2000 (a), but also the monthly hedge fund returns from January 1994 to February 2021 (b). It contains a summary of the statistics for monthly return on the aggregate hedge fund index, the nine hedge fund sub-indexes and the S\&P 500.

In the previous research, " Hedge funds posted $8.0 \%$ average annual excess returns over cash net of fees for the period, with $10.0 \%$ annualized monthly volatility, resulting in a 0.80 Sharpe ratio " [2]. When it comes to this paper, hedge funds gain $4.54 \%$ average annual excess 
returns over cash net of fees for the period, with $6.73 \%$ annualized monthly volatility, resulting in a 0.67 Sharpe ratio. Besides, the most recent statistics of annualized excess return, annualized monthly volatility, and Sharpe ratio of the aggregate index of hedge funds are lower than the previous period, $3.45 \%, 3.27 \%$ and 0.13 representatively.

To compare with the correlation of S\&P 500 in these different time frames, the 2021 dataset presented a lower correlation to S\&P 500. The correlation of S\&P 500 for the aggregate index of hedge funds from January 1994 to September 2000 was 0.52 , but 0.40 for the aggregate index of hedge funds from January 1994 to February 2021. However, the most correlated subcategories, eventdriven and long/short equity, kept the same in both periods. In 2000 dataset, the correlations of S\&P 500 of the top two correlated subcategories were 0.60 and 0.62 , respectively. In 2021 dataset, the correlations of S\&P 500 of event-driven hedge fund index were 0.54 and 0.42 for long/short equity.

According to the Sharpe ratios, it seemed that indexes highly correlated to S\&P 500 did not always have a high Sharpe ratio. That is, "not every style seems to benefit from market exposure" [2]. For instance, two of the most correlated styles in 2000 dataset generated Sharpe ratios of 1.05 and 0.94 , respectively. However, the highest sharp ratio in that period was 1.85 by equity market neutral hedge fund index, which only had a correlation of 0.48 with S\&P 500. What's more, "Convertible arbitrage funds produce impressive returns and a Sharpe ratio of 1.07 , with a very low 0.13 monthly correlation with the S\&P 500”. In 2021 dataset, event-driven and long/short equity had Sharpe ratios of 0.54 and 0.42 , respectively. In contrast, the hedge fund index of the Global Macro funds had the highest sharp ratio of 0.76 , while only showed a very low monthly correlation of 0.13 with the S\&P 500 .

In both periods, dedicated short bias funds were the only type of funds negatively correlated to the market returns. The performance of the dedicated short bias funds continued to decline in the analysis of 2021 dataset with lower annualized excess return, lower annualized sharp ratio, and lower minimum monthly return. Except for the dedicated short bias funds, managed futures maintain its second lowest correlation with the market due to the influences of CTAs, which were all close to zero in both periods [4].

\section{Table 3. MONTHLY REGRESSIONS OF EXCESS HEDGE FUND RETURNS ON CONTEMPORANEOUS}

\begin{tabular}{|c|c|c|c|}
\hline \multirow[b]{2}{*}{ Portfolio } & \multicolumn{3}{|c|}{ Monthly Regressions } \\
\hline & $\begin{array}{c}\text { Alpha } \\
\text { (Annualized \%) }\end{array}$ & $\begin{array}{l}\text { Beta vs. } \\
\text { S\&P } 500\end{array}$ & $\begin{array}{c}\text { Adjusted } \\
\mathrm{R}^{\wedge} 2 \\
\end{array}$ \\
\hline $\begin{array}{l}\text { Aggregate Hedge } \\
\text { Fund Index }\end{array}$ & $\begin{array}{c}2.63 \\
(0.76)\end{array}$ & $\begin{array}{l}0.37 \\
(5.46)\end{array}$ & $26.5 \%$ \\
\hline & 4.78 & 0.04 & $0.3 \%$ \\
\hline Convertible Arbitrage & (2.35) & (1.12) & \\
\hline & 2.93 & 0.28 & $34.9 \%$ \\
\hline Event-Driven & $(1.35)$ & (6.62) & \\
\hline & 4.69 & 0.12 & $22.2 \%$ \\
\hline Equity Market-Neutral & (3.84) & $(4.89)$ & \\
\hline $\begin{array}{l}\text { Fixed-Income } \\
\text { Arbitrage }\end{array}$ & $\begin{array}{c}1.24 \\
(0.70)\end{array}$ & $\begin{array}{c}0.02 \\
(0.71)\end{array}$ & $-0.6 \%$ \\
\hline Long/Short Equity & $\begin{array}{c}3.82 \\
(0.95)\end{array}$ & $\begin{array}{c}0.55 \\
(6.98)\end{array}$ & $37.4 \%$ \\
\hline Emerging Markets & $\begin{array}{l}-8.38 \\
(-1.15)\end{array}$ & $\begin{array}{c}0.74 \\
(5.15)\end{array}$ & $24.2 \%$ \\
\hline & 2.41 & 0.37 & $11.8 \%$ \\
\hline Global Macro & $(0.44)$ & $(3.43)$ & \\
\hline $\begin{array}{l}\text { Managed Futures } \\
\text { Hedge Fund Index }\end{array}$ & $\begin{array}{c}-1.30 \\
(-0.29)\end{array}$ & $\begin{array}{c}0.01 \\
(0.12)\end{array}$ & $-1.2 \%$ \\
\hline
\end{tabular}




$\begin{array}{lccc} & 7.34 & -0.99 & 57.0 \% \\ \text { Dedicated Short Bias } & (1.50) & (-10.34) & \end{array}$

Table 4. MONTHLY REGRESSIONS OF EXCESS HEDGE FUND RETURNS ON CONTEMPORANEOUS S\&P 500 EXCESS RETURNS JANUARY 1994-FEBRUARY 2021

\begin{tabular}{lccc}
\hline Portfolio & $\begin{array}{c}\text { Monthly Regressions } \\
\text { Alpha }\end{array}$ & $\begin{array}{c}\text { Beta vs. } \\
\text { (Annualized \%) }\end{array}$ & $\begin{array}{c}\text { S\&P 500 } \\
\mathrm{R}^{2}\end{array}$ \\
\hline Aggregate Hedge Fund Index & 3.18 & 2.30 & $15.60 \%$ \\
Convertible Arbitrage & $(2.60)$ & $(7.74)$ & $11.80 \%$ \\
Event-Driven & 2.71 & 1.84 & \\
& $(2.36)$ & $(6.59)$ & $28.80 \%$ \\
Equity Market-Neutral & 2.99 & 3.08 & \\
& $(2.71)$ & $(11.44)$ & $5.10 \%$ \\
Fixed-Income Arbitrage & 0.47 & 1.72 & \\
& $(0.28)$ & $(4.16)$ & \\
Long/Short Equity & 1.52 & 1.35 & $17.80 \%$ \\
Emerging Markets & $(1.60)$ & $(5.79)$ & \\
& 3.60 & 3.25 & $14.90 \%$ \\
Global Macro & $(2.25)$ & $(8.37)$ & $1.60 \%$ \\
Managed Futures Hedge Fund & 2.14 & 4.34 & \\
Index & $(0.91)$ & $(7.52)$ & $1.20 \%$ \\
Dedicated Short Bias & 6.16 & 0.92 & $27.60 \%$ \\
\hline
\end{tabular}

\subsection{Monthly Regressions of Excess Hedge Fund Returns}

In Table III and Table IV, monthly regressions of excess hedge fund return for both periods had been conducted. The team made use of Sharpe ratio, beta, and adjusted variance to analyze the monthly return analysis of hedge index to get the abovementioned results. Table III showed the monthly regressions of excess hedge fund returns on contemporaneous S\&P 500 excess returns based on monthly hedge fund returns data collected from January 1994 to September 2000. Table IV contained the corresponding data from January 1994 to February 2021. Although different in time period, both datasets indicated of the stability of hedge fund returns in the face of market fluctuations through a relative low level of beta and a higher excess return compared with the treasury bond.
From the perspective of the 2021 dataset, however, there were a few indexes that endured relatively dramatic changes. Firstly, the annualized alpha and beta of dedicated short bias hedge fund index shifts from $7.34 \%$ and -0.99 in the 2000 dataset to $-3.08 \%$ and -7.77 in the 2021 dataset, respectively. This change reflects the economic cycle of the United States, as the US stock market had been experiencing an 11-year bull market and providing sufficient liquidity for the financial market since 2010 hitherto, after breaking away from the aftermath of the 2008 financial crisis [7]. In such a liquid market, the risk of shorting was far greater than that of longing [8]. To deal with the market tides, hedge fund managers who dedicated to shorting need more professional analytical abilities. Many dedicated short bias funds suffered from great losses such as the funds in the case of Tesla and Gamestop [4]; Secondly, the alpha and beta of emerging markets hedge fund index had changed from $-8.38 \%$ and 0.74 in the 2000 dataset to $2.14 \%$ 
and 4.34 in the 2021dataset, respectively. Characterized by low investment, high growth rate, and high returns, companies in the emerging markets often grew faster than their peer companies outside the emerging markets. The inefficient stock pricing in emerging markets made high returns possible [9]. For example, high-tech companies such as Apple had skyrocketed in stock price in the decade-long bull market in the United States [7,10,11].
From the above analysis, hedge funds still served as an excellent tool for investment. The sub-indices of dedicated short bias and emerging markets in the hedge fund industry indicated the situation. It is the returns concentrating on shorting positions were constantly receding while the emerging markets are gradually on the rise under the broad context of the booming US economy.

Table 5. MONTHLY VERSUS QUARTERLY VOLATILITY AND MARKET CORRELATIONS JANUARY 1994SEPTEMBER 2000

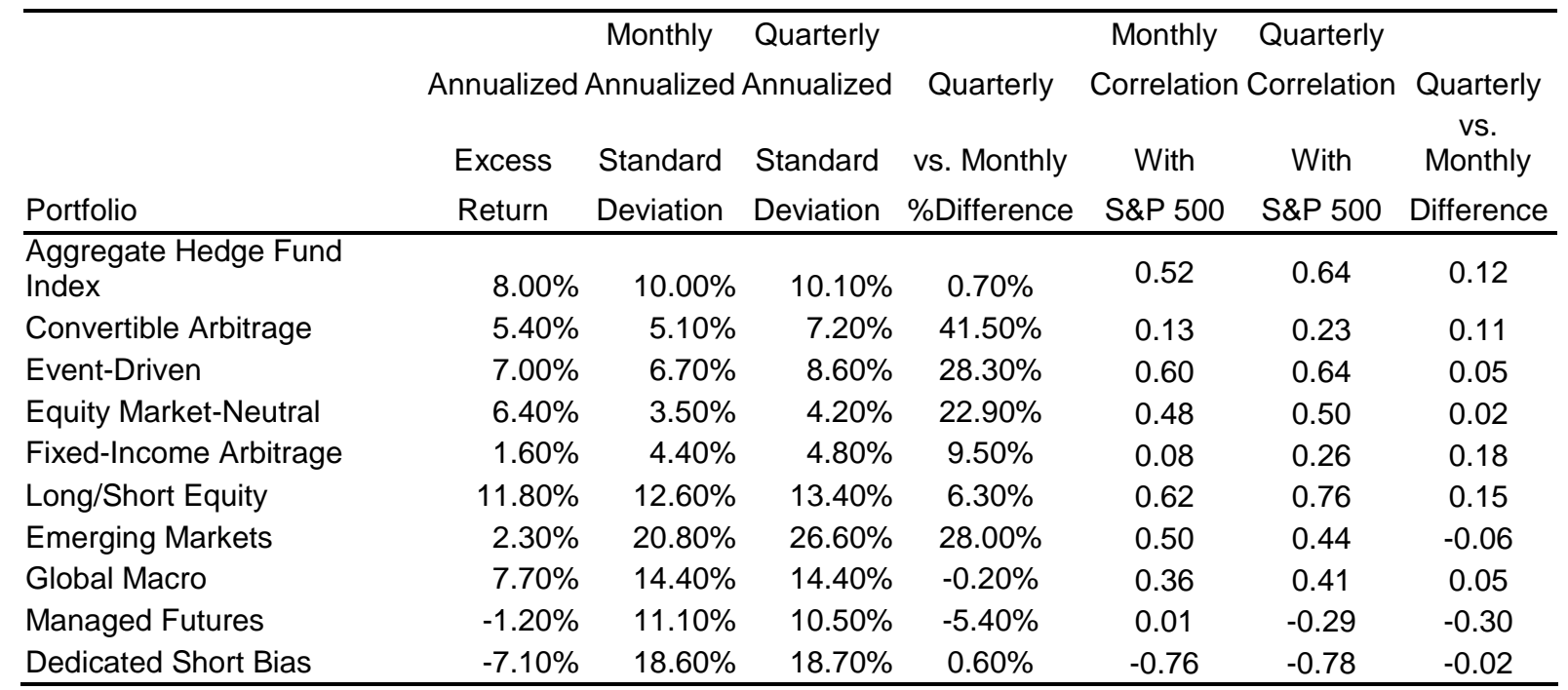

Table 6. MONTHLY VERSUS SEMI-ANNUALLY VOLATILITY AND MARKET CORRELATIONS JANUARY 1994-FEBRUARY 2021

\begin{tabular}{|c|c|c|c|c|c|c|c|}
\hline \multirow{3}{*}{ Portfolio } & & Annualized Annualized Annualized & $\begin{array}{l}6 \text { Months } \\
\text { Annualized }\end{array}$ & 6 Months & \multicolumn{2}{|c|}{ Correlation Correlation } & \multirow{2}{*}{$\begin{array}{c}6 \text { Months } \\
\text { vs. } \\
\text { Monthly }\end{array}$} \\
\hline & Excess & Standard & Standard & vs. Monthly & With & With & \\
\hline & Return & Deviation & Deviation & \%Difference & S\&P 500 & S\&P 500 & Difference \\
\hline $\begin{array}{l}\text { Aggregate Hedge Fund } \\
\text { Index }\end{array}$ & $4.54 \%$ & $6.73 \%$ & $19.46 \%$ & $189.00 \%$ & 0.40 & 0.61 & 0.21 \\
\hline Convertible Arbitrage & $3.77 \%$ & $6.18 \%$ & $22.39 \%$ & $262.00 \%$ & 0.34 & 0.54 & 0.20 \\
\hline Event-Driven & $4.90 \%$ & $6.63 \%$ & $21.66 \%$ & $227.00 \%$ & 0.54 & 0.63 & 0.09 \\
\hline Equity Market-Neutral & $1.12 \%$ & $8.82 \%$ & $23.47 \%$ & $166.00 \%$ & 0.23 & 0.34 & 0.11 \\
\hline Fixed-Income Arbitrage & $2.31 \%$ & $5.11 \%$ & $18.23 \%$ & $257.00 \%$ & 0.31 & 0.54 & 0.23 \\
\hline Long/Short Equity & $5.46 \%$ & $8.91 \%$ & $24.75 \%$ & $178.00 \%$ & 0.42 & 0.64 & 0.22 \\
\hline Emerging Markets & $4.26 \%$ & $13.01 \%$ & $38.30 \%$ & $194.00 \%$ & 0.39 & 0.43 & 0.04 \\
\hline Global Macro & $6.42 \%$ & $8.46 \%$ & $23.10 \%$ & $173.00 \%$ & 0.13 & 0.21 & 0.08 \\
\hline Managed Futures & $1.68 \%$ & $11.14 \%$ & $25.15 \%$ & $126.00 \%$ & -0.11 & -0.25 & -0.14 \\
\hline Dedicated Short Bias & $-8.44 \%$ & $16.12 \%$ & $37.61 \%$ & $133.00 \%$ & -0.53 & -0.71 & -0.18 \\
\hline
\end{tabular}

\subsection{Volatility and Market Correlations of Hedge Fund Returns}

Table V and Table VI provide results of volatility and market correlations for both periods. Although the concept of longer-horizon returns was used, data in this paper were processed for every six months to test volatility and market correlations of the monthly returns with S\&P 500 instead of quarter-based data procession in the paper Do Hedge Fund Hedge?

According to the previous research, even the results of volatility and correlation for returns with longer periods could hardly influenced by non-synchronous price reactions, the longer-horizon volatility should be higher than the shorter-horizon volatility [4]. In general, most subcategories of the hedge fund indexes were in conformity with this principle, except for managed 
futures and dedicated short bias hedge fund index in the 2000 dataset which had a lower annualized quarterly volatility. Table VI indicated that six months were effective to eliminate these exceptions. All subcategories in the dataset 2021 had a lower annualized monthly volatility compared with the annualized six-month volatility. Meanwhile, it could be observed that sixmonth volatility was also higher than that of a quarter. The highest quarterly volatility was $41.5 \%$ in Table V, while Table VI presented a highest six-month volatility of $262 \%$.

Furthermore, compared with the result of the 2000 dataset, market correlations of the 2021 dataset had an increasing trend for longer-horizon returns. For the aggregate hedge fund index, market correlation with S\&P 500 , increased not only in quarterly returns but also in semi-annual returns. In the 2000 dataset, the correlation of the quarterly returns of the aggregate hedge fund index with S\&P 500 rose to 0.64 from 0.52 . In the 2021 dataset, the correlation of the 6-month returns of the aggregate hedge fund index with the S\&P 500 rose to 0.61 from 0.40 . Nevertheless, there were expectations among subcategories in both datasets. Managed futures and dedicated short bias hedge fund index show a declining correlation with longer-horizon returns. For example, in the 2000 dataset, the correlation of the quarterly returns of the managed futures hedge fund index with S\&P 500 dropped to -0.29 from 0.01 . In 2021 dataset, the correlation of the 6-month returns of the dedicated short bias hedge fund index with the S\&P 500 decrease to -0.71 from -0.53 .

\section{CONCLUSION AND RECOMMENDATION}

In conclusion, most results of this paper verify viewpoints in Do Hedge Fund Hedge? except for the differences. By updating to the most recent data, the overstated issue of the hedge funds is common and visible, therefore the following conclusions can be reached: Firstly, the correlation with S\&P 500 seems to drop according to the updating data; secondly, hedge fund returns maintain its stability of high returns even faced with market fluctuations; Thirdly, longer-horizon returns show a higher market correlation along with a higher volatility. As a result, the authors recommends that investors consider the serious discrepancy of the hedge funds and review the decent reports when they want to apply hedge funds strategies for either reducing risks or gain high returns over periods.

\section{REFERENCES}

[1] Saltwell, H. (2021, April 08). Hedge fund performance by strategy - latest data.

[2] Seta, M. D., Morellec, E., \& Zucchi, F. (2020). Short-term debt and incentives for risk- taking. Journal of Financial

Economics. doi:10.1016/j.jfineco.2019.07.008

[3] Cao, C., Farnsworth, G., \& Zhang, H. (2021). The economics of hedge Fund STARTUPS: Theory and empirical evidence. The Journal of Finance. doi:10.1111/jofi.13009

[4] Asness, Cliff S. and Krail, Robert and Liew, John M., Do Hedge Funds Hedge? (May 2001).

[5] Adrian, T., Crump, R. K., \& Moench, E. (2015). Regression-based estimation of dynamic asset pricing models. Journal of Financial Economics, 118(2), 211244. doi:10.1016/j.jfineco.2015.07.004

[6] Kramer, L. (2021, January 28). Long position vs. short position: What's the difference?

[7] Rapach, D. E., Ringgenberg, M. C., \& Zhou, G. (2016). Short interest and aggregate stock returns. Journal of Financial Economics, 121(1), 4665. doi:10.1016/j.jfineco.2016.03.004

[8] Robinson, C. (2001). Stock Price Behaviour in a Small Emerging Market: Tests for Predictability and Seasonality on the Barbados Stock Exchange / Savings and Development, 25(1), 103-115.

[9] Floyd, E., Li, N., \& Skinner, D. J. (2015). Payout policy through the financial crisis: The growth of repurchases and the resilience of dividends. Journal of Financial Economics, 118(2), 299316. doi:10.1016/j.jfineco.2015.08.002

[10] Cho, T. (2020). Turning alphas into betas: Arbitrage and endogenous risk. Journal of Financial Economics. doi:10.1016/j.jfineco.2020.02.011

[11] Ye, K., Yan, J., Wang, S., Wang, H., \& Miao, B. (2011). Knowledge level modeling for systemic risk management in financial institutions. Expert Systems with Applications, 38(4), 35283538. doi:10.1016/j.eswa.2010.08.141 